\title{
Pola Asuh Orangtua Terhadap Dorongan Aktivitas Belajar dan Hasil Belajar Siswa Sekolah Dasar Di Kabupaten Maros
}

\section{Parenting Styles towards the Encouragement of Learning Activities and Learning Outcomes of Elementary School Students in Maros Regency}

\author{
Rahmah $^{1}$, Mas'ud Muhammadiah², Sundari Hamid² \\ ${ }^{1}$ Dinas Pendidikan Kota Makassar, Sulawesi Selatan \\ 2Program Studi Studi Pendidikan Dasar, Program Pascasarjana, Universitas Bosowa
}

E-mail: rahmapgsd2013@gmail.com

Diterima: 14 Juli 2020/Disetujui 07 Desember 2020

\begin{abstract}
Abstrak. Penelitian ini bertujuan untuk mencari tahu bagaimana orangtua memberi motivasi belajar dan prestasi belajar di Sekolah Dasar Kabupaten Maros pada tahun ajaran 2018/2019. Sampel dalam penelitian ini terdiri dari tiga sekolah yang ada di kabupaten Maros. Metode yang di gunakan dalam pengumpulan data adalah angket dan dokumentasi, data diolah dengan menghitung nilai rata-rata indeks skor perdimensi pola asuh dan rumus presentase untuk menganalisis pengaruh motivasi belajar. Hasil penelitian terdapat pola asuh yang berbeda yang diterapkan orangtua. Pola asuh demokratis lebih cenderung digunakan. Dengan nilai skor rata-rata indeks skor sebesar 61,3, dan perkembangan prestasi belajar anak nilai rata-rata indeks skor 81,23 ada selalu memberi pengaruh pola asuh orangtua terhadap keinginan belajar meningkat, maka hasil belajar sekolah dasar di Kabupaten Maros juga meningkat.
\end{abstract}

Kata Kunci: Orang Tua, Pola Asuh, Motivasi, Hasil Belajar, Maros

\begin{abstract}
This study aims to find out how parents encourage learning motivation and learning achievement of Primary School Students in Maros Regency for academic year 2018/2019. The sample in this study consisted of three schools in Maros Regency. The methods used in data collection are questionnaires and documentation. The data is processed by calculating the average index score for each dimension of parenting and the percentage formula to analyze the effect of learning motivation. The results of the study show that there are different parenting styles implemented by parents. Democratic parenting is more likely to be used. With an average index score of 61.3, and the development of children's learning achievement, with average index score of 81.23 , there is always an effect of parenting on learning motivation to increase, so the learning outcomes of primary schools in Maros Regency also increase.
\end{abstract}

Keywords: Parents, Parenting, Motivation, Learning Outcomes, Maros

\section{Pendahuluan}

Pendidikan yaitu proses pendidik dengan sengaja dan penuh tanggung jawab memberi pengaruh terhadap perkembangan anak (Silvana, 2011). Pendidikan memiliki peranan dalam pembangunan bangsa dan Negara karena dari kecerdasan dan kemampuan dimasa yang akan datang berpengaruh terhadap pendidikan saat ini. Pendidikan berperang untuk membentuk kemampuan atau pemikiran manusia yang mempunyai daya saing dan kemampuan menyerap perkembngan teknologi yang dapat meningkatkan produktivitas. Oleh karna itu manusia berhak memperoleh pendidikan.

Pendidikan merupakan salah satu kebutuhan primer dan usaha sadar yang dilakukan seseorang dalam mengembangkan bakat atau minat seseorang, serta pengalaman yang didapatkan di lingkungan sekolah atau dilingkungan masyarakat, pendidikan juga merupakan dasar pertama dan paling utama yang harus kita miliki sejak diri seseorang dalam suatu lingkungani. Pendidikan diartikan sebagai suatu kegiatan yang dilakukan bekal dasar untuk dimasa deapn. Tujuan pendidikan termasuk gambaran tentang hal baik untuk kehidupan juga merupakan suatu tanggung jawab kita bersama, baik masyarakat dan pemerintahan. Sekolah sangat membantu kelanjutan kesejakteraan dan membantu keluarga, karena pendidikan yang pertama dan utama yang didapatkan anak adalah keluarga. Sikap anak terhadap sekolah akan dipengaruhi oleh orangtua mereka orangtua harus memperhatikan pengalamannya dan menghargai usahanya serta menunjukkan kerja samanya dalam cara mendidik anak dalam belajar dirumah atau membuat pekerjaan rumah. Orangtua merupakan dasar pertama bagi pembentukan pribadi anak dan membentuk baik buruknya perilaku anak. Orangtua juga merupakan salah satu penunjang membentuk kepribadian anak atau tingkahlaku anak dalam rumah maupun di lingkungan. Pendidikan merupakan kebutuhan primer di dunia.

Salah satunya yaitu pendidikan di dalam keluarga yang secara langsung didapatkan dari orangtua. Pendidikan yang didapatkan dalam orangtua termasuk bagian Pola asuh orangtua yang berbeda mengetahui perkembangan anak yaitu demokrati, otoriter dan permisif. Pola asuh demokratis cara yang dimiliki orangtua yang bersifat lebih terbuka untuk anak, pola asuh otoriter adalah pola asuh yang bersifat kerjasama orangtua dengan anak, pola asauh otoriter pola asauh yang bersifat keras terhadap anak. karena orangtua tidak hanya terbatas memiliki keturunan saja tetapi menyangkut berbagai 
bidang keluarga. Pola asuh orangtua sangat dibutuhkan oleh anak untuk mendorong motivasi belajar dan prestasi belajar, sehingga anak termotivasi untuk belajar guna meningkantkan semanagat belajar serta prestasi belajar meningkat.

Pendidikan saat ini sangat berpengaruh dengan perkembangan teknolgi yang semakin canggih, siswa dapat mencari informasi melalui alat komunikasih baik berupa hp, laptop dan berbagai macam alat informasi lainnya. Untuk hal itu guru juga harus memiliki keterampilan dalam menggunakan teknologi sehingga guru dan siswa dapat bekerjasama dalam memecahkan suatu masalah.

Pola asuh orangtua juga dapat mempengaruhi pertumbuhan perkembangan anak termasuk motivasi belajar, dan prestasi belajar anak. Apabila orangtua mendidik anaknya di rumah dengan baik maka perilaku anak dilingkungan dan dimasyarakat akan tetap baik (Iman, 2011). Tetapi sebaliknya apabila orangtua mendidik anaknya dengan cara tidak baik maka perilakua anak dilingkungan masyarakat akan tidak baik. Kondisi berbeda yang didapatkan anak dilingkungan dan keluarga maka anak biasanya pemalas. Untuk Mendukung tercapai keberhasilnya atau prestasi yang baik bagi anak salah satunya adalah belajar (Djali, 2018). Hasil belajar yang didapatkan anak tidaklah sama ada yang mencapi prestasi yang tinggi, cukup, sedang dan rendah.

Untuk lebih menjelaskan betapa berharganya keluarga bagi setiap anak yang nantinya akan turung lansung kedalam masyarakat.

segala kebutuhan hidup mengenai pendidikan, keluarga tadi merupakan kesatuab yang menghasilkan kebutuhabn yang dibutuhkan anak (Jainuddin, 2019). Dalam mengajari anak, tempat utama menuntut ilmu pendidikan anak adalah apa yang telah dilakukan orangtua dirumah (Aswar, 2012). Berhasil baik tidaknya pendidikan disekolah tergantung pengaruh pendidikan yang di dapat dalam keluarga. Pendidikan seorang ibu kepada anaknya tidak dapat diacuhkan begitu saja, dari itu kita hendak menjadi seorang yang bijaksana dan pandai mengatur anak karena sebagian orang mengatakan orangtua adalah pendidik bangsa.

Disitulah pendidikan, mempunyai batas aturan di dalam keluarga untuk meningkatkan kepribadian individu agar menjadi manusia yang cerdas, sebab karena itu bnyak msalah yang tercakup dalam dunia pendidikan maka tidaklah kaget apabila dalam proses pendidikan pada umumnya, sering pula muncul berbagai problem (Sulistyo, 2012). Masalah ini tersebut mucul dari kesalahan pelaku pendidikan itu sendiri atau mungkin waktu menjelaskan begitu cepat berlangsung, yang berintangan dengan dunia yang berbeda dengan sebelumnya. Dengan perkembangan dan tantangan yang makin pesat seperti saat ini (nurul, 2019). Guru idealnya terus berusaha untuk biasa menamnah wawasan pengetahuannya serta terus- menerus meyesuaikan cara mengajar melalui dengan penemuan baru dalam dunia pendidikan. Hampir semua orang pernah memiliki pendidikan, tetapi tidak semua orang tahu apa itu pendidikan.

Dengan dasar pendidik membutuhkan pemahaman berbagi teori pendidik yang berkembang di berbagai Negarang lain. Ada berbagai macam bagian yang termasuk bagian yang menentukan perkembangan suatu pendidikan disekolah, serta masyarakat, dan keterlibatan keluarga semua harus bejalan seirama dan saling mendukung antara satu dengan yang lainnya untuk menjamin mutu pendidikan

Factor dari luar kondisi atau keadaan keluarga. Faktor motivasi belajar dipengaruhi oleh anak itu sendiri. Ada anak yang betul-betul mau belajar, ada juga yang asal-asalan dalam belajar, ada juga anak dia lebih fokus dalam mengikuti pelajaran. Peranan pola asuh orangtua secara umum dapat dikatakan mempunyai hubungan positif terhadap motivasi belajar dan prestasi belajar anak disebabkan anak membutukan bimbingan dan pengawasan orangtua dalam banak belajar sangat memerlukan bimbingan belajar. Keluarga bagian ilmu social dikenal oleh anak. keutuhan anak contohnya: anak dalam belajar membutuhkan bimbingan atau pengawasan orangtua, sehingga anak biasa termotivasi untuk belajar.

Pendidikan membantu proses pembentukan pemikiran anak dalam berinteraksi kepada orangtua. Orangtua dapat memberikan perhatian yang lebih mendalam pada pertumbuhan dan perkembangan skill anak apabila anak mendapat pola asuh yang tepat maka prestasi belajar akan baik (Purwanto, 2006). Dari hasil observasi dilapangan, ditemukan beberapa permasalahan yaitu dimana orangtua memiliki cara mendidik yang berbeda-beda. Demokratis, permisif, dan otoriter (Surakhmad, 2016). Berdasarkan hal tersebut peneliti siap untuk melakukan penelitian dengan tujuan menganalisis pengaruh pola asuh orang tua terhadap motivasi belajar dan prestasi siswa sekolah dasar di Kabupaten Maros.

Penelitian ini bertujuan untuk mencari tahu bagaimana orangtua memberi motivasi belajar dan prestasi belajar di Sekolah Dasar Kabupaten Maros pada tahun ajaran 2018/2019.

\section{Metode Penelitian}

Jenis ini adalah expost facto yang besifat korelasional dari hasil penyelidikan secara nyata yang tidak mampu peneliti mengendalikan variabel bebas secara langsung, karena variabel tersebut pada dasarnya tidak dapat dibuat buat. penelitian expost facto dimana peneliti berusaha menentukan penyebab atau alasan suatu perbedaaan perilaku dalam status kumpulan individu (Sugiyono, 2016). Dengan kata lain, telah diamati bahwa kelompok berbeda pada beberapa variabel peniliti berusaha mengidentifikasi faktor utama yang mendasari perbedaan tersebut.

Lokasi tempat penelitian di Kabupaten Maros ditiga sekolah yang mewakili tiga kecamatan yang terpilih. Nama sekolah antara lain: SD 102 Inpres Takkalasi (Marusu), SD Inpres Tekolabbua (Maros Baru), dan SD Negeri 64 Malaka (Cenrana). Cara yang digunakan dalam Pengumpulan data pola asuh, data keinginan belajar siswa, dan hasil belajar. Untuk mengumpulkan suatu dapat dilakukan menggunakan kosioner angket pola asuh, dan keinginan belajar serta hasil belajar siswa yang didapatkan selama mengikuti proses pembelajaran.

1. Angket 
Angket digunakan mengumpulkan data perhatian orang tua dan motivasi belajar. Penilaian angket menggunakan skala likert dengan kategori selalu (dilakukan setiap hari dalam seminggu), sering (dilakukan lebih dari 4 kali dalam seminggu), jarang (dilakukan kurang dari 4 kali dalam seminggu) dan tidak pernah (tidak pernah dilakukan dalam seminggu).

2. Dokumentasi

Dokumentasi digunakan untuk mengumpulkan data sekolah yang memuat:

a. Keadaan siswa dari setiap sekolah.

b. prestasi belajar nilai atau hasil belajar peserta didik dari masing-masing sekolah. tahun ajaran 2018/2019. Hasil belajar ini di peroleh dari nilai buku rapor siswa.

Uji analisis data yang digunakan berupa:

1. Uji deskriptif, untuk melihat sebaran data

2. Uji statistik inferensial, untuk mengetahui signifikansi

3. Uji prasyarat, berupa uji linearitas dabn multikoloniaritas

4. Uji Regresi sederhana, untuk melihat besar pengaruh

Semua uji analisis di atas dibantu menggunakan aplikasi SPSS Versi 21

\section{Hasil dan Pembahasan}

Hasil dan pembahasan dalam penelitian ini menguraikan tentang perubahan penggunaan lahan dan keselarasan rencana pola ruang di Kota Kendari. Pembahasan tersebut dijabarkan sebagai berikut:

a. Pola Asuh Orangtua

Data bagian Pola asuh diperoleh dari angket sebanyak 24 nomor pertanyaan dan banyaknya 55 responden. Berdasarkan Pola asuh orangtua yang diolah skor tertinggi 96 dan skor terendah 24.

Tabel 1 Skor Pola Asuh Orangtua

\begin{tabular}{|c|c|c|c|c|}
\hline No & Panjang Skor & Kategori & Jumlah & presentase (\%) \\
\hline 1 & $24-36$ & Rendah & 2 & $5,45 \%$ \\
\hline 2 & $37-48$ & Kurang & 18 & $34 \%$ \\
\hline 3 & $60-72$ & Sedang & 21 & $38,18 \%$ \\
\hline \multicolumn{3}{|c|}{ Jumlah } & 55 & 100 \\
\hline
\end{tabular}

Sumber: Analisa Data 2020.

b. Motivasi Belajar

Data dari motivasi diperoleh pertanyaan 16 butir jumlah responden 55 orang. Dari motivasi belajar di peroleh skor terendah 16, skor tertinggi 64

Tabel 2 Skor Variabel Motivasi Belajar

\begin{tabular}{ccccc}
\hline No & RentangSkor & Bagian & Banyak & Frekuensi (\%) \\
\hline 1 & $16-24$ & Rendah & 6 & $11 \%$ \\
2 & $26-32$ & Kurang & 21 & $38,18 \%$ \\
3 & $40-48$ & Sedang & 16 & $29 \%$ \\
4 & $56-64$ & Tinggi & 12 & $22 \%$ \\
\hline & Jumlah & & 55 & 100 \\
\hline
\end{tabular}

Sumber: Analisa Data 2020.

\section{c. Prestasi Belajar}

Hasil belajar diambil dari cara memperoleh data nilai keseluruhan akhir semester genap tahun pelajaran 2018/2019 semester II Dari semua siswa. Bedasarkan bagian hasil belajar di dapatkan skor tinggi 91.

Tabel 3 Hasil Variabel Prestasi Belajar

\begin{tabular}{lllcc}
\hline No & Tingkatan skor & Bagian & Banyak & Frekuensi (\%) \\
\hline 1 & $60<65$ & Rendah & 19 & $35 \%$ \\
2 & $70<75$ & Kurang & 22 & $40 \%$ \\
3 & $81<86$ & Sedang & 2 & $4 \%$ \\
4 & $85<91$ & Tinggi & 12 & $21,18 \%$ \\
\hline
\end{tabular}

Sumber: Analisa Data 2020.

Hasil analisis deskriptif pada variabel pola asuh orangtua Sekolah dasar di Kabupaten Maros pada kategori tertinggi sebanyak 53\%. Sedangkan hasil analisis deskriftif pada variabel motivasi belajar Sekolah Dasar di Kabupaten Maros pada kategori tinggi sebanyak 67\%. Selanjutnya hasil analisis deskriptif pada variabel pretasi belajar Sekolah Dasar di Kabupaten Maros pada kategori tinggi sebanyak $80 \%$. Berdasarkan uraian diatas dapat disimpulkan bahawa adanya pengaruh pola asuh orang tua terhadap motivasi belajar dan hasil belajar sekolah dasar di kabupaten maros sangat erat.

\section{Kesimpulan dan Saran}

Hasil penelitian dapat disimpulkan bahwa didikan Orangtua Terhadap Motivasi Belajar Sekolah Dasar di Kabupaten Maros adalah positif yang berarti pengaruhnya signifikan. Terdapat pengaruh positif antara Pola asuh orangtua dengan 
prestasi belajar Sekolah Dasar di Kabupaten Maros berarti pengaruh signifikan kontribusinya nyata. Pengaruh pola asuh Orangtua terhadap keinginan belajar dan prestasi belajar sekolah dasar di kabupaten maros berpengaruh signifikan kontribusinya nyata.

\section{Daftar Pustaka}

BPS,2018 .Kota Kendari Dalam Angka tahun 2018, Kendari:BPS Kota Kendari.

Azwar, Saifuddin. (2012). Penyusunan Skala Psikologi. Yoyakarta: Pustaka Pelajar.

Djaali. (2008).Psikologi Pendidikan.Jakarta: Bumi Aksara.

Imam Ghozali. (2011). AplikasiAnalisis Multivariate dengan Program IMB SPSS 19, Semarang: Badan PenerbitUniversitasDiponegoro.

Henterington, M. EdanPorke,R.D.(1999) Child Psychology A Conterporaryn new point 4th new york:Graw Hill.inc

Purwanto, Ngalim. (2006).PsikologiPendidikan.Bandung: PT. Remaja Rosdakarya.

Sugihartono, dkk. (2007). Psikologi Pendidikan. Yogyakarta: UNY Press.S

Sugiyono. 2016. Metode penelitian kuantitatif kualitatatif dan R dan D. Bandung Alfabeta

Sulistyo, Joko. (2012). Enam Hari Jago SPSS 17. Yogyakarta: Cakrawala.

Suharsimi Arikunto. (2005). Managemen Penelitian Edisi Revisi. Jakarta: Rineka Cipta.

Supriyanto, Aji.(2005).Pengantar Teknologi Informasi.Jakarta:Salemba Infotek.

Surakhmad, Winarno. 2016. Pengantar pendidikan ilmiah. Bandung Tarsito.

Nurul Fadhi.http://digilib.unimus.ac.id/files/disk1/110/jtptunimus-gdl-nurulfadhi5489-4-babii.pdf(akses 5 Februari 2019).

Silvana Yudha, Metha." Pengaruh Pola Asuh Orang Tua Tunggal Terhadap Perilaku Moral Remaja”.S1, fakultas Ilmu Pendidikan Sosial dan Universitas Pendidikan Indonesia, Bandung, 2011.

Jainuddin, J., \& Sirajuddin, S. (2020). Pengaruh Minat dan Kedisiplinan Siswa dengan Gaya Kognitif Field Indefendent terhadap Hasil Belajar Matematika Siswa SMK Farmasi Yamasi Makassar. Delta-Pi: Jurnal Matematika dan Pendidikan Matematika, 9(2).

Jainuddin, J. (2019). Peningkatan Hasil Belajar Matematika Melalui Latihan Menyelesaikan Soal Secara Sistematis Pada Siswa Kelas XI. IPA1 SMA Negeri 2 Sungguminasa. Klasikal: Journal Of Education, Language Teaching and Science, 1(3), 44-52.

http://teorionline.wordpress.com/2010/01/25/teori-motivasi-herzberg-danmcclelland/tanggal akses 11 februari 2019. 